\title{
P021: Effect of urinary tract infections at multiresistant bacteria (MRB) in hospital of Dakar
}

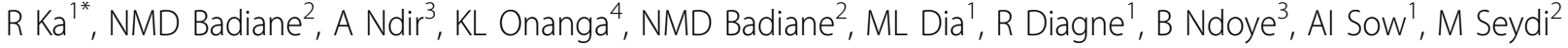 \\ From 2nd International Conference on Prevention and Infection Control (ICPIC 2013) \\ Geneva, Switzerland. 25-28 June 2013
}

\section{Introduction}

The control of the spread of BMR in health facilities is a national priority in Senegal.

\section{Objectives}

Our work aims to study the incidence of urinary tract infections due to BMR in a university hospital.

\section{Methods}

Microbiological monitoring was conducted in three inpatient wards of a university hospital from April to October 2012 and concerned only diagnostic urinalysis.

\section{Results}

During the study period, 123 patients were followed up and 79 urine samples were made corresponding to $56.4 \%$ of all diagnostic samples. The average age of patients was $55 \pm$ 21.22 and sex ratio of 0.97 . Thirty-nine percent of patients were admitted with a neurological disorder. These patients were referred by another health facility $(56.3 \%)$ came from home (34.4\%) or had undergone internal transfer (9.4\%). The attack rate of urinary tract infections was 3.96. These urinary tract infections were of nosocomial acquisition in 56 cases $(78.9 \%)$ with an average delay of 12.75 days. The bacteria isolated were Enterobacteriaceae 61 (77.2\%), non-fermenting Gram-negative bacilli $14(17.7 \%)$ and staphylococci 4 (5.1\%). In order of frequency, these were Escherichia coli 25 (31.6\%), Klebsiella pneumoniae 21 (26.6\%), Pseudomonas 8 (10.2\%) and Enterobacter 5 (6.3\%). We found 32 strains (40.5\%) producing extended-spectrum beta-lactamase (ESBL) and 2 strains (2.5\%) of Staphylococcus aureus resistant to methicillin (MRSA). From urinary tract infections associated with ESBL Enterobacteriaceae urinary catheter was potentially the source of infection in 18 cases. BMR attack rate was 1.80 per 100 admissions and

${ }^{1}$ Department of Bacteriology, CHU Fann, Senegal

Full list of author information is available at the end of the article the incidence rate of 1.99 BMR for 1000 days patients. To wane, 18 patients or $30 \%$ died.

\section{Conclusion}

The decrease in the incidence of nosocomial urinary tract infections must be accompanied by antibiotic stewardship and a strict hygiene policy.

\section{Disclosure of interest}

None declared.

\section{Author details}

'Department of Bacteriology, CHU Fann, Senegal. 'Department of Infectious Diseases, CHU Fann, Senegal. ${ }^{3}$ PRONALIN, Ministère of Health and Social Action, Dakar, Senegal. ${ }^{4}$ Department of Bacteriology, Fann Hospital, Dakar, Senegal.

Published: 20 June 2013

doi:10.1186/2047-2994-2-S1-P21

Cite this article as: Ka et al.: P021: Effect of urinary tract infections at multiresistant bacteria (MRB) in hospital of Dakar. Antimicrobial Resistance and Infection Control 2013 2(Suppl 1):P21.

Submit your next manuscript to BioMed Central and take full advantage of:

- Convenient online submission

- Thorough peer review

- No space constraints or color figure charges

- Immediate publication on acceptance

- Inclusion in PubMed, CAS, Scopus and Google Scholar

- Research which is freely available for redistribution

\section{Biomed Central}

(c) 2013 Ka et al; licensee BioMed Central Ltd. This is an Open Access article distributed under the terms of the Creative Commons Attribution License (http://creativecommons.org/licenses/by/2.0), which permits unrestricted use, distribution, and reproduction in any medium, provided the original work is properly cited. 